\title{
Climate Change with Reference to Green Economy: Carbon Accounting of Hamdard University
}

\author{
Muhammad Nabeel Ashraf \\ Lecturer \\ Hamdard University Karachi-Pakistan \\ m.nabeelashraf@live.co.uk, \\ m.nabeelashraf@live.co.uk; \\ $\&$ \\ Prof. Dr. Syed Shabib-ul-Hassan \\ Vice Chancellor \\ Hamdard University \\ Karachi - Pakistanis \\ huvc@hamdard.edu.pk
}

\begin{abstract}
Hamdard University is one of the biggest private sector universities in Pakistan. It is a not-for-profit organization whose objective is to serve people of Pakistan with excellent education system while taking care external factors into consideration, as a part of its Corporate Social Responsibility (CSR), especially the environment which is a key concern due to the climate change. This research paper focusses on measuring the carbon footprint or performing the carbon accounting of Hamdard University and to measure its share in climate change. Primary data, which is necessary to measure carbon footprint, have been taken by direct reporting and site surveys. Methodology and secondary data regarding the emission factors have been taken from Intergovernmental Panel on Climate Change, World Resources Institute, Word Bank, Greenhouse Gas Protocol, and U.S. Environmental Protection Agency. The carbon footprint of Hamdard University is 1786.2019 tonnes of $\mathrm{CO}_{2}-\mathrm{e}$ in 2018 which is $0.000547 \%$ of Pakistan 2014's total GHG emission. Scope 1 emission constitutes $54.14 \%$ of total GHG emission which is mostly caused by the fuel combustion by varsity's transport followed by scope 2 emission caused by purchased electricity which constitutes $45.32 \%$ of GHG total emission. Scope 3 emission is


because of official air travel which is not significant, hence, constitutes $0.54 \%$ of total GHG emission.

Keywords: Carbon Footprint, Carbon Accounting, Climate Change, Hamdard University, Environmental Accounting, Green Economy.

\section{Introduction}

Although Pakistan produced 326.7740 Megatonnes (Mt) of $\mathrm{CO}_{2}$-e which is $0.72 \%$ of Global GHG emission in 2014 (World Resourse Institute, 2014). In spite of this, Pakistan is among the 10 most affected countries by climate change in the world (Kreft, Eckstein, Junghans, Kerestan, \& Hagen, 2015).

Developing countries are estimated to be the most vulnerable to climate change (Cole, 2008) therefore adaptation is most important for these countries to offset the effects of climate change (Farber, 2007). Extreme weather events in Pakistan have made people and organization think about the environment. Civil society and businesses started taking green initiatives to adapt to the climate change and Hamdard University is no exception.

Hamdard University is one of the biggest private sector universities in Pakistan. Hamdard University is a not-for-profit university, its goal is to serve the nation of Pakistan while taking care the external factors into consideration including the environment which is a key concern due to the climate change. Although it is not mandatory for organizations to report greenhouse gas emission in Pakistan, yet in this research paper, we will perform the carbon accounting for Hamdard University as a Corporate Social Responsibility (CSR) to report the carbon footprint to all stakeholders.

\section{Literature Review}

\section{Climate Change}

Climate change is a long-term change of the earth's climate or it occurs when earth's climate results in new weather patterns for a long period of time usually a few decades to a million of years. Climate change is also referred to as global 


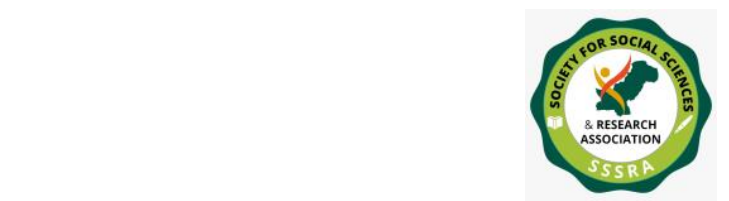

warming which occurs due to the presence of greenhouse gasses into the earth's atmosphere. Currently the earth has been warming more rapidly than ever before and it is caused by the anthropogenic factors (America's Climate Choices: Panel on Advancing the Science of Climate Change; National Research Council, 2010). Global warming leads to extreme weather events, sea level rise, melting glaciers, natural disasters, etc. It causes huge cost to the global economy due to which measuring the impact and its mitigation is very important which leads to the concept of green economy.

\section{Green Economy}

The impact of climate change is very severe and to mitigate the impact, governments have started moving toward the green economy, the economy with low-carbon emission and resource efficient (United Nations Environment Programme, 2011). Governments and organizations have started reducing the carbon emission and going toward the green products which are also called carbon-neutral products. The first step toward the green economy is to measure the carbon emission and then to reduce the carbon emission which you just measured and Hamdard University has started to contribute toward the goal of green economy by measuring and reducing the carbon footprint.

\section{Carbon Accounting}

Carbon accounting is the process to measure the amount of carbon dioxide equivalents emitted by the organization in a specified reporting period. Carbon accounting helps us quantify the amount of greenhouse gasses emitted directly and indirectly from the organization's activities with a set of boundaries. It is used to gather data that may be useful to assess the impact of climate change and carbonrelated decision making (Lippert, 2011). The term carbon footprint is interchangeably used for carbon accounting.

\section{Carbon Footprint}

Footprint means the impact made by person or activity. This metaphor was first used in 1990 by William Rees, a Canadian ecologist, in the context of energy (Cleveland \& Morris, 2015). He then, along with Mathis Wackernagel, develop the concept of ecological footprint (Cleveland \& Morris, 2015). Since then the term has been used with carbon, as carbon footprint. 


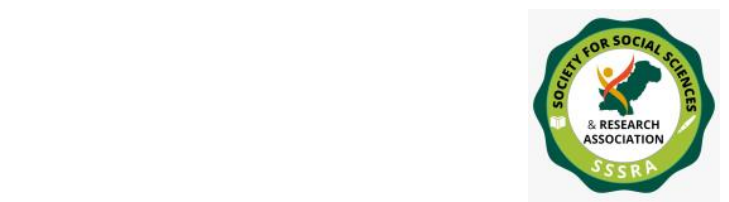

Climate Change with Reference to ...

Carbon footprint is the impact of carbon dioxide $\left(\mathrm{CO}_{2}\right)$ and other greenhouse gases (GHG), excluding the water vapor $\left(\mathrm{H}_{2} \mathrm{O}\right)$, to our earth's atmosphere through anthropogenic sources, which is the main cause of our current climate change or global warming.

Major greenhouse gases $(\mathrm{GHG})$ consists of Water vapor $\left(\mathrm{H}_{2} \mathrm{O}\right)$, Carbon dioxide $\left(\mathrm{CO}_{2}\right)$, Methane $\left(\mathrm{CH}_{4}\right)$, Nitrous oxide $\left(\mathrm{N}_{2} \mathrm{O}\right)$, Ozone $\left(\mathrm{O}_{3}\right)$, Chlorofluorocarbons (CFCs) and Hydrofluorocarbons (incl. HCFCs and HFCs). Greenhouse gases creates the greenhouse effect which warms the earth's surface. Water vapor and clouds contributes $50 \%$ and $25 \%$ while carbon dioxide and other greenhouse gases contributes $20 \%$ and $5 \%$ to the greenhouse effect respectively (Schmidt, Ruedy, Miller, \& Lacis, 2010). Current climate change is caused by the emission of greenhouse gases by anthropogenic sources. Hence, water vapor is not directly caused by humans, therefore, we exclude it from carbon footprint. Other greenhouse gases have different lives and therefore different Global Warming Potential (GWP) with respect to carbon dioxide. Therefore we measure these greenhouse gases with respect to carbon dioxide and the output is called Carbon Dioxide Equivalent $\left(\mathrm{CO}_{2}-\mathrm{e}\right)$. The carbon dioxide contributes significantly in greenhouse effect (after excluding water vapor) as compared to other greenhouse gases, due to which, the term carbon footprint is used for greenhouse gases as a general term.

The term carbon footprint gained popularity in early 2000 and researchers have started using this regularly since 2008 (Cleveland \& Morris, 2015). The term climate footprint is sometimes used to include all other human-emitted greenhouse gases, which are not even carbon-based.

\section{Background}

On 12 December 2015, 196 countries which participated in the 21st yearly session of the Conference of the Parties (COP) to the 1992 United Nations Framework Convention on Climate Change (UNFCCC) agreed by consensus, to the Paris Agreement, to keep the global warming well below $2^{\circ} \mathrm{C}$ (Chappell, 2015) (CBC News, 2015). The member countries agreed to reduce their carbon or greenhouse gas emission as soon as possible to limit the global warming. The Paris Agreement requires each country to voluntarily set the carbon or greenhouse gas inventory reduction target and register it to UNFCCC Secretariat after every five year as a 


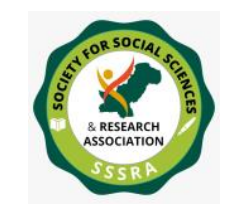

Climate Change with Reference to ...

Nationally Determined Contribution (NDC) (United Nations Framework Convention on Climate Change, 2015).

\section{Recent Developments}

Not only governments but civil society and businesses are on board too. As a matter of fact, some companies have already joined the climate change initiatives that supports the Paris Agreement and have started making sense to talk about Business Determined Contributions (BDC) (We Mean Business, CDP and NewClimate Institute, 2016). Businesses could cut almost $60 \%$ of total greenhouse gas emission promised in Paris Agreement by NDC or 3.2-4.2 billion tons of $\mathrm{CO}_{2}$ equivalent per year by 2030 (We Mean Business, CDP and NewClimate Institute, 2016). It is almost 7-9\% of global greenhouse gas emission of 2010 (We Mean Business, CDP and NewClimate Institute, 2016). Business Determined Contributions (BDCs) could potentially cut by almost 10 billion tons (We Mean Business, CDP and NewClimate Institute, 2016) of greenhouse gas emission but with the support of the government to make right policies for all relevant companies signing up to these initiatives.

Organizations significantly contributes to country's carbon emission in which they operate. Therefore, some countries have made it compulsory for organization to report their carbon emission annually, while others have not. Hence, some companies practice the carbon accounting to report the greenhouse gas emission to stakeholders each year as a requirement by the governments. On the other hand, some companies measure the carbon footprint and report it to all stakeholders as a part of Corporate Social Responsibility (CSR) even if it is not required by the government.

\section{Research Methodology}

The methodology is which is used to measure the carbon footprint of Hamdard University is taken from the report of "The World Bank Group Greenhouse Gas Emissions Inventory Management Plan for Internal Business Operations 2014" (The World Bank, 2015) which is as per international standards.

\section{Emission boundary}


Organization boundary for carbon accounting is established on the basis of operational control approach (Commonwealth of Australia, 2017) which includes the Hamdard University main campus only.

\section{Emission sources within the boundary}

Hamdard University emission sources are classified as scope 1 (direct emission sources), scope 2 (indirect emission sources) and scope 3 (operational sources).

\section{Scope 1 emission}

Scope 1 emission of Hamdard University includes:

i. Fuel combustion for electricity generation by backup generators.

ii. Emission from fuel combustion that is Petrol, and Diesel in University's vehicles.

iii. Emission from the consumption of natural gas.

iv. Emission from refrigerants

v. Emission from vehicle's refrigerants

\section{Scope 2 emission}

Scope 2 emission of varsity consists of:

i. Emission from purchased electricity from K-electric.

\section{Scope 3 emission}

Hamdard University scope 3 emission are from the following activities.

i. Business Travel.

\section{Greenhouse Gas Inventory}

Out of from six major greenhouse gasses, Hamdard University greenhouse gas Inventory includes $\mathrm{CO}_{2}, \mathrm{CH}_{4}, \mathrm{~N}_{2} \mathrm{O}$, HFCs, PFCs excluding $\mathrm{SF}_{6}$ which doesn't have known emissions. HFCs and CFCs are optional to include in GHG inventory according to GHG Protocol.

\section{Excluded Emissions Sources}


Following emission sources are excluded on the basis of relevance or materiality principle (Commonwealth of Australia, 2017).

i. Data regarding the Fertilizers used in horticulture is not available and very limited in amount and hence not material to include.

\section{Base year}

This research paper focuses on carbon footprint of 2018. Hamdard University has never accounted for carbon emission before, therefore the base year is 2018 .

\section{Data collection on emissions sources}

All the data is collected through direct reporting and site surveys of Hamdard University.

\section{Emission Factors}

The emission factors, which are used to calculate the greenhouse gas emission of Hamdard University, are taken from different sources used in the report of The World Bank Group Greenhouse Gas Emissions Inventory Management Plan for Internal Business Operations 2014. These emission factors are according to the international standards and guidelines of the World Resources Institute (WRI) and the World Business Council for Sustainable Development's (WBCSD) Greenhouse Gas Protocol Initiative (GHG Protocol) for its internal corporate greenhouse gas accounting and reporting.

\section{Data Analysis and Emission Calculation}

\section{Scope 1; Direct Emission Sources}

It is the emission which is directly caused by the organization's activities within the established boundary.

\section{Emission from fuel (petrol) combustion by backup generators}

Hamdard University consumed petrol of PKR. 1765678.21 in 2018 for electricity generation purpose from backup generators. The amount in PKR is divided by the average price of petrol each month, taken from the Petroleum Oil Lubricants 
(POL) Archives at PSO website (Pakistan State Oil, n.d.) due to non-availability of data in volume, equals to 19591.6056 liters. Emissions from greenhouse gasses $\mathrm{CO}_{2}, \mathrm{CH}_{4}$ and $\mathrm{N}_{2} \mathrm{O}$ in tonnes of carbon dioxide equivalent are estimated as follows:

\section{Emissions of carbon dioxide}

$\mathrm{CO}_{2}$ Emission $=$ Fuel Usage Quantity (energy) $\times$ Fuel-Specific $\mathrm{CO}_{2}$ Emissions Factor (kg/MMBtu)

\section{-Equation 1}

First we need to convert the fuel quantity from volume which is in liters to the MMBtu which is a unit of energy called one million British Thermal Units (BTU). 19591.6056 liters of petrol is equal to 5175.5547 gallons of petrol and 1 gallons of petrol is equal to 0.124 MMBtu which is a heat content of motor gasoline $^{1}$. Now multiply the heat content to the total number of gallons to get the Fuel Usage Quantity in units of energy which is equal to 641.7688 MMBtu. Fuelspecific emission factor of $\mathrm{CO}_{2}, \mathrm{CH}_{4}$ and $\mathrm{N}_{2} \mathrm{O}$ for motor gasoline is 73.1115, $0.01055,0.00063 \mathrm{~kg} / \mathrm{MMBtu}$ respectively. ${ }^{2}$ 100-year $\mathrm{GWP}$ of $\mathrm{CH}_{4}$ and $\mathrm{N}_{2} \mathrm{O}$ is 25 and 298 times that of $\mathrm{CO}_{2}$ which is used to convert these gases to carbon dioxide equivalent $\left(\mathrm{CO}_{2}-\mathrm{e}\right){ }^{3}$ Now substitute the values in equation 1 , we get:

$$
\begin{aligned}
\mathrm{CO}_{2} \text { emission }= & 641.7688 \mathrm{MMBtu} \times 73.1115 \mathrm{~kg} / \mathrm{MMBtu} \\
= & 46920.6796 \mathrm{~kg} \mathrm{CO} 2=46.9207 \text { tonnes } \mathrm{CO}_{2}
\end{aligned}
$$

\section{Emissions of methane}

$\mathrm{CO}_{2}$-e Emission of $\mathrm{CH}_{4}=$ Fuel Usage Quantity (energy) $\times$ Fuel-Specific $\mathrm{CH}_{4}$ Emissions Factor $\times \mathrm{CH}_{4} \mathrm{GWP}$

\section{-Equation 2}

25

$\mathrm{CO}_{2}$-e emission of $\mathrm{CH}_{4}=641.7688 \mathrm{MMBtu} \times 0.01055 \mathrm{~kg} / \mathrm{MMBtu} \times$

\footnotetext{
1 Source: WRI. Calculation Tool for Direct Emissions from Stationary Combustion. Calculation worksheets. December 2007. Version 3.1 (The World Bank, 2015)

${ }^{2}$ Source: WRI. Calculation Tool for Direct Emissions from Stationary Combustion.
} 


$$
=169.2665 \mathrm{~kg} \mathrm{CO}_{2}-\mathrm{e}=0.1693 \text { tonnes } \mathrm{CO}_{2}-\mathrm{e}
$$

\section{Emissions of nitrous oxide}

$\mathrm{CO}_{2}$-e Emission of $\mathrm{N}_{2} \mathrm{O}=$ Fuel Usage Quantity (energy) $\times$ Fuel-Specific $\mathrm{N}_{2} \mathrm{O}$ Emissions Factor $\times \mathrm{N}_{2} \mathrm{O}$ Global Warming Potential (GWP) ---.---.---.-Equation 3

$$
\mathrm{CO}_{2} \text {-e emission of } \mathrm{N}_{2} \mathrm{O}=641.7688 \mathrm{MMBtu} \times 0.00063 \mathrm{~kg} / \mathrm{MMBtu} \times
$$

$$
=120.4856 \mathrm{~kg} \mathrm{CO}_{2}-\mathrm{e}=0.1205 \text { tonnes } \mathrm{CO}_{2}-\mathrm{e}
$$

Total emission from petrol combustion by backup generators

$$
\begin{aligned}
& =46.9207+0.1693+ \\
& 0.1205 \\
& =47.2105 \text { tonnes } \mathrm{CO}_{2}-
\end{aligned}
$$

$\mathrm{e}$

\section{Emission from combustion of natural gas}

Hamdard University consumed 3541.6726 MMBtu of natural gas in 2018. Fuel-specific emission factors of $\mathrm{CO}_{2}, \mathrm{CH}_{4}$ and $\mathrm{N}_{2} \mathrm{O}$ for natural gas is 52.9515, $0.005275,0.0001055 \mathrm{~kg} / \mathrm{MMBtu}$ respectively. ${ }^{4} 100$-year $\mathrm{GWP}$ of $\mathrm{CH}_{4}$ and $\mathrm{N}_{2} \mathrm{O}$ is 25 and 298 times that of $\mathrm{CO}_{2}{ }^{5}$ Emissions from greenhouse gasses $\mathrm{CO}_{2}, \mathrm{CH}_{4}$ and $\mathrm{N}_{2} \mathrm{O}$ in tonnes of carbon dioxide equivalent are estimated as follows:

\section{Emissions of carbon dioxide}

$\mathrm{CO}_{2}$ Emission = Fuel Usage Quantity (energy) $\times$ Fuel-Specific $\mathrm{CO}_{2}$ Emissions Factor (kg/MMBtu)

\section{---------Equation 4}

$$
\begin{aligned}
\mathrm{CO}_{2} \text { emission }=3541.6726 \mathrm{MMBtu} \times 52.9515 \mathrm{~kg} / \mathrm{MMBtu} \\
=187536.8767 \mathrm{~kg} \mathrm{CO} 2=187.5368767 \text { tonnes } \mathrm{CO}_{2}
\end{aligned}
$$

\section{Emissions of methane}

\footnotetext{
${ }^{4}$ Source: WRI. Calculation Tool for Direct Emissions from Stationary Combustion. Calculation worksheets. December 2007. Version 3.1 (The World Bank, 2015)

${ }^{5}$ Intergovernmental Panel on Climate Change, Fourth Assessment Report
} 
$\mathrm{CO}_{2}$-e Emission of $\mathrm{CH}_{4}=$ Fuel Usage Quantity (energy) $\times$ Fuel-Specific $\mathrm{CH}_{4}$ Emissions Factor $\times \mathrm{CH}_{4} \mathrm{GWP}$

\section{-Equation 5}

$\mathrm{CO}_{2}$-e emission of $\mathrm{CH}_{4} \quad=3541.6726 \mathrm{MMBtu} \times 0.005275 \mathrm{~kg} / \mathrm{MMBtu}$

$\mathrm{CO}_{2}-\mathrm{e}$

$$
=467.0581 \mathrm{~kg} \mathrm{CO} 2-\mathrm{e}=0.4670581 \text { tonnes }
$$

\section{Emissions of nitrous oxide}

$\mathrm{CO}_{2}$-e Emission of $\mathrm{N}_{2} \mathrm{O}=$ Fuel Usage Quantity (energy) $\times$ Fuel-Specific $\mathrm{N}_{2} \mathrm{O}$ Emissions Factor $\times \mathrm{N}_{2} \mathrm{O}$ Global Warming Potential (GWP)

\section{Equation 6}

$\begin{array}{r}\mathrm{CO}_{2} \text {-e emission of } \mathrm{N}_{2} \mathrm{O} \\ \mathrm{kg} / \mathrm{MMBtu} \times 298\end{array}$
3.541704 tonnes $\mathrm{CO}_{2}-\mathrm{e}$

Total emission from combustion of natural gas

$$
\begin{aligned}
& =187.5368767+0.4670581+ \\
& 3.541704 \\
& =191.5456 \text { tonnes } \mathrm{CO}_{2}-\mathrm{e}
\end{aligned}
$$

\section{Emission from petrol combustion in transport}

Hamdard University consumed 152573 liters of petrol in 2018 for transport purposes by varsity's vehicles. Fuel-specific emission factors of $\mathrm{CO}_{2}, \mathrm{CH}_{4}$ and $\mathrm{N}_{2} \mathrm{O}$ for mobile fuel emission factor is $0.002327152 \mathrm{tCO}_{2} \mathrm{eq} / \mathrm{l}, 0.00008737$, $0.0000469 \mathrm{~kg} / \mathrm{l}$ respectively. ${ }^{[6][7]} 100$-year GWP of $\mathrm{CH}_{4}$ and $\mathrm{N}_{2} \mathrm{O}$ is 25 and 298 times that of $\mathrm{CO}_{2}{ }^{8}$ Emissions from greenhouse gasses $\mathrm{CO}_{2}, \mathrm{CH}_{4}$ and $\mathrm{N}_{2} \mathrm{O}$ in tonnes of carbon dioxide equivalent are estimated as follows:

\section{Emissions of carbon dioxide}

\footnotetext{
${ }^{6}$ WRI. CO2 Emissions from Business Travel. Version 2.0. (The World Bank, 2015)

${ }^{7}$ Source: GHG Protocol Stationary and Mobile Emission Factors, Table 7 (The World Bank, 2015)

${ }^{8}$ Intergovernmental Panel on Climate Change, Fourth Assessment Report
} 
$\mathrm{CO}_{2}$ Emission $=$ Fuel Usage Quantity (volume) $\times$ Fuel-Specific $\mathrm{CO}_{2}$ Emissions Factor

\section{-Equation 7}

$$
\begin{gathered}
\mathrm{CO}_{2} \text { emission }=152573 \text { liters } \times 0.002327152 \mathrm{tCO}_{2} \mathrm{eq} / 1 \\
=355.0606 \text { tonnes } \mathrm{CO}_{2}
\end{gathered}
$$

\section{Emissions of methane}

$\mathrm{CO}_{2}$-e Emission of $\mathrm{CH}_{4}=$ Fuel Usage Quantity (volume) $\times$ Fuel-Specific $\mathrm{CH}_{4}$ Emissions Factor $\times \mathrm{CH}_{4} \mathrm{GWP}$

\section{-Equation 8}

$\mathrm{CO}_{2}$-e Emission of $\mathrm{CH}_{4} \quad=152573$ liters $\times 0.00008737 \mathrm{~kg} / \mathrm{l} \times 25$

$$
=333.2576 \mathrm{~kg} \mathrm{CO}_{2}-\mathrm{e}=0.3333 \text { tonnes } \mathrm{CO}_{2}-\mathrm{e}
$$

\section{Emissions of nitrous oxide}

$\mathrm{CO}_{2}$-e Emission of $\mathrm{N}_{2} \mathrm{O}=$ Fuel Usage Quantity (volume) $\times$ Fuel-Specific $\mathrm{N}_{2} \mathrm{O}$ Emissions Factor $\times \mathrm{N}_{2} \mathrm{O}$ GWP

\section{-Equation 9}

$$
\begin{aligned}
\mathrm{CO}_{2}-\mathrm{e} \text { Emission of } \mathrm{N}_{2} \mathrm{O} & =152573 \text { liters } \times 0.0000469 \mathrm{~kg} / \mathrm{l} \times 298 \\
& =2132.3908 \mathrm{~kg} \mathrm{CO} \mathrm{CO}_{2}-\mathrm{e}=2.1324 \text { tonnes } \mathrm{CO}_{2}-
\end{aligned}
$$

Total emission from petrol combustion in transport

$$
\begin{aligned}
& =355.0606+0.3333+2.1324 \\
& =357.5263 \text { tonnes } \mathrm{CO}_{2}-\mathrm{e}
\end{aligned}
$$

\section{Emission from diesel combustion in transport}

Hamdard University consumed 71799 liters of Diesel in 2018 for transport purposes. Fuel-specific emission factors of $\mathrm{CO}_{2}, \mathrm{CH}_{4}$ and $\mathrm{N}_{2} \mathrm{O}$ for mobile fuel emission factor is $0.002699055 \mathrm{tCO}_{2} \mathrm{eq} / \mathrm{l}, 2.90621 \mathrm{E}-06,5.81242 \mathrm{E}-06 \mathrm{~kg} / \mathrm{l}$ respectively. ${ }^{[9][10]} 100$-year GWP of $\mathrm{CH}_{4}$ and $\mathrm{N}_{2} \mathrm{O}$ is 25 and 298 times that of

\footnotetext{
${ }^{9}$ WRI. CO2 Emissions from Business Travel. Version 2.0 (The World Bank, 2015)

${ }^{10}$ Source: GHG Protocol Stationary and Mobile Emission Factors, Table 7 (The World Bank, 2015)
} 
$\mathrm{CO}_{2 .}{ }^{11}$ Emissions from greenhouse gasses $\mathrm{CO}_{2}, \mathrm{CH}_{4}$ and $\mathrm{N}_{2} \mathrm{O}$ in tonnes of carbon dioxide equivalent are estimated as follows:

\section{Emissions of carbon dioxide}

$\mathrm{CO}_{2}$ Emission $=$ Fuel Usage Quantity (volume) $\times$ Fuel-Specific $\mathrm{CO}_{2}$ Emissions Factor

\section{---------Equation 10}

$$
\begin{gathered}
\mathrm{CO}_{2} \text { emission }=71799 \text { liters } \times 0.002699055 \mathrm{tCO}_{2} \mathrm{eq} / 1 \\
=193.7895 \text { tonnes } \mathrm{CO}_{2}
\end{gathered}
$$

\section{Emissions of methane}

$\mathrm{CO}_{2}$-e Emission of $\mathrm{CH}_{4}=$ Fuel Usage Quantity (volume) $\times$ Fuel-Specific $\mathrm{CH}_{4}$ Emissions Factor $\times \mathrm{CH}_{4} \mathrm{GWP}$

\section{Equation 11}

$$
\begin{aligned}
\mathrm{CO}_{2} \text {-e Emission of } \mathrm{CH}_{4} \quad & =71799 \text { liters } \times 2.90621 \mathrm{E}-06 \mathrm{~kg} / \mathrm{l} \times 25 \\
& =71799 \times 0.00000290621 \times 25 \\
& =5.2166 \mathrm{~kg} \mathrm{CO} \mathrm{CO}_{2}-\mathrm{e}=0.0052166 \text { tonnes } \mathrm{CO}_{2}-
\end{aligned}
$$$$
\text { e }
$$

\section{Emissions of nitrous oxide}

$\mathrm{CO}_{2}$-e Emission of $\mathrm{N}_{2} \mathrm{O}=$ Fuel Usage Quantity (volume) $\times$ Fuel-Specific $\mathrm{N}_{2} \mathrm{O}$ Emissions Factor $\times \mathrm{N}_{2} \mathrm{O}$ GWP

\section{Equation 12}

$$
\begin{aligned}
\mathrm{CO}_{2} \text {-e Emission of } \mathrm{N}_{2} \mathrm{O} \quad & 71799 \text { liters } \times 5.81242 \mathrm{E}-06 \mathrm{~kg} / \mathrm{l} \times 298 \\
& =71799 \times 0.00000581242 \times 298 \\
= & 124.3631 \mathrm{~kg} \mathrm{CO}_{2}-\mathrm{e}=0.1243631 \text { tonnes } \mathrm{CO}_{2}-\mathrm{e}
\end{aligned}
$$

Total emission from diesel combustion in transport

$$
\begin{aligned}
& =193.7895+0.0052166+ \\
0.1243631 & \\
= & 193.9190 \text { tonnes } \mathrm{CO}_{2}-\mathrm{e}
\end{aligned}
$$

\section{Emission from refrigerants}

${ }^{11}$ Intergovernmental Panel on Climate Change, Fourth Assessment Report 
Air conditioners, refrigerants and freezer utilize various GHGs which include primarily HFCs and PFCs. These equipment do not intentionally release these GHGs into the atmosphere, but sometimes they do it as a result of maintenance, installation, disposal, and operational leakage. Their 100-year GWP is 140 to 11700 times that of $\mathrm{CO}_{2}$ due to which their impact on climate change can be substantial (U.S. Environmental Protection Agency, 2004). Each refrigerant $\mathrm{CO}_{2}$-e is calculated by taking the product of the mass of refrigerant and their respective Global Warming Potential (GWP). There are several methods to calculate $\mathrm{CO}_{2}-\mathrm{e}$ as per the GHG Protocol.

\section{Method}

Data regarding the each unit of refrigerant, its type etc. is the hardest piece of information to collect. Due to the non-availability of this type of data, we use the method which yields the approximate value. It is based on the refrigerant emission rate (ton refrigerant emitted/ft ${ }^{2} /$ year) based on the occupied Hamdard University building area.

Total tonnes $\mathrm{CO}_{2}$-e from Refrigerants = Estimated Refrigerant Recharge Quantity $\times$ Refrigerant-Specific GWP Equation 13

First, we need to find out the estimated refrigerant recharge amount of the Hamdard University.

\section{Estimated Refrigerant Recharge Amount}

Estimated refrigerant recharge amount $=$ estimated area per ton of cooling $\times$ conversion factor of one ton of cooling per one $\mathrm{kg}$ of refrigerant charge $\times$ an assumed leakage rate

\section{------Equation 14}

\section{Estimated area per ton of cooling}

1 ton of cooling per $500 \mathrm{ft}^{2}$ (HVAC rule of thumb) (The World Bank, 2015). Hamdard University has $653161 \mathrm{ft}^{2}$ covered area which is approximately equal to 1306.322 ton of cooling.

\section{Conversion factor}


Conversion factor of one ton of cooling per one $\mathrm{kg}$ of refrigerant charge. Refrigerant charge per cooling ton ( $\mathrm{kg} / \mathrm{ton}$ ) is equal to $1 \mathrm{~kg}$ per cooling ton (U.S. Environmental Protection Agency, 2004) which is equal to $1306.322 \mathrm{~kg}$.

\section{Assumed leakage rate}

Annual operating loss factor $=10 \%$ (U.S. Environmental Protection Agency, 2004)

Substituting these value in equation 14 to get the estimated refrigerant recharge amount.

Estimated refrigerant recharge amount

$=1306.322$ ton of cooling $\times 1 \mathrm{~kg}$ per cooling ton $\times 10 \%$ assumed leakage rate

$=130.6322 \mathrm{~kg}$ which is 0.1306322 tonnes

\section{Refrigerant Specific GWP}

Refrigerant type is not known therefore we assume the refrigerant type to be HFC-R134a as it is the most common type of refrigerant which is mostly used in all refrigerants (The World Bank, 2015). GWP of HFC-R134a is 1300 (Intergovernmental Panel on Climate Change, 1996). Substituting estimated refrigerant recharge amount and GWP of the refrigerant type specified in equation 13 to get total $\mathrm{CO}_{2}$-e from Refrigerants.

Total tonnes $\mathrm{CO}_{2}$-e from Refrigerants

$$
\begin{aligned}
& =0.1306322 \text { tonnes } \times 1300 \text { Years } \\
& =169.8219 \text { tonnes } \mathrm{CO}_{2}-\mathrm{e}
\end{aligned}
$$

\section{Emission from vehicles refrigerants}

Total $\mathrm{CO}_{2}$-e from vehicles refrigerants $=$ Annual refrigerant loss $\times$ Refrigerant Specific GWP

\section{--------Equation 15}

\section{Annual refrigerant loss}

Annual refrigerant loss $=$ No. of owned vehicles $\times$ Standard refrigerant charge per vehicle $\times$ Standard operating loss factor

\section{Equation 16}




\section{No. of owned vehicles}

Hamdard University has 34 passenger vehicles.

\section{Standard refrigerant charge per vehicle}

It is 0.8 for passenger vehicles (Recycling \& Refrigerants, 2004)

\section{Standard operating loss factor}

It is $20 \%$ (The World Bank, 2015).

Substituting these values in equation 16 to get the annual refrigerant loss in $\mathrm{kg}$.

Annual refrigerant loss $=34 \times 0.8 \times 20 \%$

$$
=5.44 \mathrm{~kg}
$$

\section{Refrigerant Specific GWP}

All passenger cars are assumed to use r-134a type refrigerant which has 1300 GWP (Intergovernmental Panel on Climate Change, 1996). Substituting all these values in equation 15 to get the total $\mathrm{CO}_{2}$-e from vehicles refrigerants.

Total $\mathrm{CO}_{2}$-e from vehicles refrigerants $\quad=5.44 \mathrm{~kg} \times 1300$

$$
=7072 \mathrm{~kg}=7.072 \text { tonnes of }
$$

\section{$\mathrm{CO}_{2}-\mathrm{e}$}

Summary

Total Scope 1 emission

\begin{tabular}{lll}
\hline Source & Tonnes $\mathrm{CO}_{2}$-e & Percentage \\
\hline $\begin{array}{l}\text { Emission from fuel (petrol) combustion by } \\
\text { generators }\end{array}$ & 47.2105 & $4.88 \%$ \\
Emission from combustion of natural gas & 191.5456 & $19.81 \%$ \\
Emission from petrol combustion in transport & 357.5263 & $36.96 \%$ \\
Emission from diesel combustion in transport & 193.9190 & $20.05 \%$ \\
Emission from refrigerants & 169.8219 & $17.56 \%$ \\
Emission from vehicles refrigerants & 7.072 & $0.73 \%$ \\
Total Scope 1 emission & 967.0953 & $100 \%$ \\
\hline
\end{tabular}

Scope 2; Indirect Emission Sources 
Although this emission is not directly caused by the organization's activities but organization's activities consumes this or requires them (producers) to produce more that is the reason it comes under the head of indirect emission.

\section{Emission from purchased electricity}

Hamdard University consumed $1966825 \mathrm{kWh}$ which is equal to 1966.825 MWh of purchased electricity in 2018. Fuel-specific emission factors of $\mathrm{CO}_{2}, \mathrm{CH}_{4}$ and $\mathrm{N}_{2} \mathrm{O}$ for mobile fuel emission factor is 902, 0.070, $0.012 \mathrm{lb} / \mathrm{MWh}$ respectively. ${ }^{12}$ 100-year GWP of $\mathrm{CH}_{4}$ and $\mathrm{N}_{2} \mathrm{O}$ is 25 and 298 times that of $\mathrm{CO}_{2}{ }^{13}$ Emissions from greenhouse gasses $\mathrm{CO}_{2}, \mathrm{CH}_{4}$ and $\mathrm{N}_{2} \mathrm{O}$ in tonnes of carbon dioxide equivalent are estimated as follows:

\section{Emissions of carbon dioxide}

$\mathrm{CO}_{2}$ emission $=$ Purchased Electricity $(\mathrm{MWh}) \times$ Region Specific Emissions Factor for $\mathrm{CO}_{2}(\mathrm{lb} / \mathrm{MWh})$

\section{Equation 17}

$$
\begin{aligned}
\mathrm{CO}_{2} \text { emission }= & 1966.825 \mathrm{MWh} \times 902 \mathrm{lb} \mathrm{CO}_{2} / \mathrm{MWh} \\
& =1774076.15 \mathrm{lb} \mathrm{CO}_{2}=804.7074 \text { tonnes } \mathrm{CO}_{2}
\end{aligned}
$$

\section{Emissions of methane}

$\mathrm{CO}_{2}$-e emission of $\mathrm{CH}_{4}=$ Purchased Electricity $(\mathrm{MWh}) \times$ Region Specific Emissions Factor for $\mathrm{CH}_{4}(\mathrm{lb} / \mathrm{MWh}) \times \mathrm{CH}_{4} \mathrm{GWP}$

\section{Equation 18}

$$
\begin{array}{r}
\mathrm{CO}_{2} \text { emission of } \mathrm{CH}_{4}=1966.825 \mathrm{MWh} \times 0.070 \mathrm{lb} \mathrm{CH} / \mathrm{MWh} \times 25 \\
=3441.9438 \mathrm{lb} \mathrm{CO}_{2}-\mathrm{e}=1.5613 \text { tonnes } \mathrm{CO}_{2}-\mathrm{e}
\end{array}
$$

\section{Emissions of nitrous oxide}

\footnotetext{
${ }^{12} \mathrm{CO} 2$ Emssion Factors from Year 2011 factors from table "CO2 Emissions from CO2 emissions per $\mathrm{kWh}$ from

electricity generation", page 110, an excerpt from the IEA document "CO2 Emissions from Fuel Combustion

- Highlights (2013 Edition)", IEA, Paris.

CH4/N2O: International Electricity Emission Factors by Country, 1999-2002.xls. International Energy

Agency, as cited by EIA for 1605 b.

${ }^{13}$ Intergovernmental Panel on Climate Change, Fourth Assessment Report
} 
$\mathrm{CO}_{2}$-e emission of $\mathrm{N}_{2} \mathrm{O}=$ Purchased Electricity $(\mathrm{MWh}) \times$ Region Specific Emissions Factor for $\mathrm{N}_{2} \mathrm{O}(\mathrm{lb} / \mathrm{MWh}) \times \mathrm{N}_{2} \mathrm{O}$ GWP

\section{Equation 19}

$$
\begin{array}{r}
\mathrm{CO}_{2} \text { emission of } \mathrm{N}_{2} \mathrm{O}=1966.825 \mathrm{MWh} \times 0.012 \mathrm{lb} \mathrm{N}_{2} \mathrm{O} / \mathrm{MWh} \times 298 \\
=7033.3662 \mathrm{lb} \mathrm{CO}_{2}-\mathrm{e}=3.1903 \text { tonnes } \mathrm{CO}_{2}-\mathrm{e}
\end{array}
$$

Total emissions from purchased electricity

$$
\begin{aligned}
& =804.7074+1.5613+3.1903 \\
& =809.459 \text { tonnes } \mathrm{CO}_{2}-\mathrm{e}
\end{aligned}
$$

Summary

Total Scope 2 Emission

\begin{tabular}{lll}
\hline Source & Tonnes $\mathrm{CO}_{2}$-e & Percentage \\
\hline Emission from purchased electricity & 809.459 & $100 \%$ \\
Total Scope 2 emission & 809.459 & $100 \%$ \\
\hline
\end{tabular}

\section{Scope 3; Other Indirect Emission Sources}

Scope 3 emission is the indirect emission which occur as a result of organizational activities but not owned or controlled by the organization. Scope 3 emission is optional to report and comes under voluntary reporting.

\section{Emission from business air travel}

Emission from air travel is included in the GHG inventory as a voluntary source of scope 3. Data is collected from PRO office from all travelled destinations in 2018. First we convert the destination data in to the miles travelled for which we used the onlince calculator https://www.greatcirclemapper.net/en/great-circlemapper.html?route=OPKC-OPLA\&aircraft $=\&$ speed $=$ and then we categories the type of trip in short (<300 miles), medium (300-2,300 miles) or long haul $(>2,300$ miles). Hamdard University air travel lies in the medium-haul flights and long-haul flights.

\section{Emission from Medium-Haul flights}

Hamdard University employees travelled 42766 miles in medium haul flight category in 2018. Medium-haul emission factors of $\mathrm{CO}_{2}, \mathrm{CH}_{4}$ and $\mathrm{N}_{2} \mathrm{O}$ for air travel is $0.168 \mathrm{kgCO}_{2} /$ passenger-mile, 0.0008, $0.0053 \mathrm{~g} /$ passenger-mile 
respectively. ${ }^{14} 100$-year GWP of $\mathrm{CH}_{4}$ and $\mathrm{N}_{2} \mathrm{O}$ is 25 and 298 times that of $\mathrm{CO}_{2}{ }^{15}$ Emissions from greenhouse gasses $\mathrm{CO}_{2}, \mathrm{CH}_{4}$ and $\mathrm{N}_{2} \mathrm{O}$ in tonnes of carbon dioxide equivalent are estimated as follows:

\section{Emissions of carbon dioxide}

$\mathrm{CO}_{2}$ emission $=$ Distance Travelled $($ miles $) \times$ Medium-Haul Emission Factor $\left(\mathrm{CO}_{2} /\right.$ Passenger-mile $)$

\section{--Equation 20}

$\mathrm{CO}_{2}$ emission $=42766$ miles $\times 0.168 \mathrm{kgCO} /$ passenger-mile $=7184.688 \mathrm{kgCO}_{2}=7.184688$ tonnes $\mathrm{CO}_{2}$

\section{Emissions of methane}

$\mathrm{CO}_{2}$-e emission $=$ Distance Travelled $($ miles $) \times$ Medium-Haul Emission Factor $\left(\mathrm{CH}_{4} /\right.$ Passenger-mile $) \times \mathrm{CH}_{4} \mathrm{GWP}$

\section{-Equation 21} $\times 25$

$\mathrm{CO}_{2}$-e emission of $\mathrm{CH}_{4}=42766$ miles $\times 0.0008 \mathrm{gCH}_{4} /$ passenger-mile

$$
=855.32 \mathrm{gCO}_{2}-\mathrm{e}=0.00085532 \text { tonnes } \mathrm{CO}_{2}-\mathrm{e}
$$

\section{Emissions of nitrous oxide}

$\mathrm{CO}_{2}$-e emission of $\mathrm{N}_{2} \mathrm{O}=$ Distance Travelled (miles) $\times$ Medium-Haul Emission Factor $\left(\mathrm{N}_{2} \mathrm{O} /\right.$ Passenger-mile $) \times \mathrm{N}_{2} \mathrm{O}$ GWP

\section{-----Equation 22}

$\mathrm{CO}_{2}$ emission of $\mathrm{N}_{2} \mathrm{O}=42766$ miles $\times 0.0053 \mathrm{gN}_{2} \mathrm{O} /$ passenger-mile $\times 298$

$$
\begin{aligned}
& =67544.6204 \mathrm{gCO}_{2}-\mathrm{e} \\
& =0.0675446204 \text { tonnes } \mathrm{CO}_{2}-\mathrm{e}
\end{aligned}
$$

Total emissions from Medium-Haul flights

$$
\begin{aligned}
& =7.184688+0.00085532+ \\
& 0.0675446204 \\
& =7.2531 \text { tonnes } \mathrm{CO}_{2}-\mathrm{e}
\end{aligned}
$$

\footnotetext{
${ }^{14}$ Source: 2011 Guidelines to Defra / DECC's GHG Conversion Factors for Company Reporting. Version 1.0 FINAL updated July 2011. (The World Bank, 2015)

${ }^{15}$ Intergovernmental Panel on Climate Change, Fourth Assessment Report
} 


\section{Emission from Long-Haul flights}

Hamdard University employees travelled 12288 miles in long-haul flight category in 2018. Long-haul emission factors of $\mathrm{CO}_{2}, \mathrm{CH}_{4}$ and $\mathrm{N}_{2} \mathrm{O}$ for air travel is $0.193 \mathrm{kgCO}_{2} /$ passenger-mile, $0.0008,0.0062 \mathrm{~g} /$ passenger-mile respectively. ${ }^{16} 100$ year GWP of $\mathrm{CH}_{4}$ and $\mathrm{N}_{2} \mathrm{O}$ is 25 and 298 times that of $\mathrm{CO}_{2 .}{ }^{17}$ Emissions from greenhouse gasses $\mathrm{CO}_{2}, \mathrm{CH}_{4}$ and $\mathrm{N}_{2} \mathrm{O}$ in tonnes of carbon dioxide equivalent are estimated as follows:

\section{Emissions of carbon dioxide}

$\mathrm{CO}_{2}$ emission $=$ Distance Travelled $($ miles $) \times$ Long-Haul Emission Factor $\left(\mathrm{CO}_{2}\right.$ /Passenger-mile)

\section{Equation 23}

$\mathrm{CO}_{2}$ emission $=12288$ miles $\times 0.193 \mathrm{kgCO}_{2} /$ passenger-mile

$$
=2371.584 \mathrm{kgCO}_{2}=2.371584 \text { tonnes } \mathrm{CO}_{2}
$$

\section{Emissions of methane}

$\mathrm{CO}_{2}$-e emission $=$ Distance Travelled $($ miles $) \times$ Long-Haul Emission Factor $\left(\mathrm{CH}_{4}\right.$ /Passenger-mile $) \times \mathrm{CH}_{4} \quad \mathrm{GWP}$

\section{Equation 24}

$\mathrm{CO}_{2}$-e emission of $\mathrm{CH}_{4}=12288$ miles $\times 0.0008 \mathrm{gCH}_{4} /$ passenger-mile

$$
=245.76 \mathrm{gCO}_{2}-\mathrm{e}=0.00024576 \text { tonnes } \mathrm{CO}_{2}-\mathrm{e}
$$

\section{Emissions of nitrous oxide}

$\mathrm{CO}_{2}$-e emission of $\mathrm{N}_{2} \mathrm{O}=$ Distance Travelled (miles) $\times$ Long-Haul Emission Factor $\left(\mathrm{N}_{2} \mathrm{O} /\right.$ Passenger-mile $) \times \mathrm{N}_{2} \mathrm{O}$ GWP

\section{---Equation 25}

$\mathrm{CO}_{2}$ emission of $\mathrm{N}_{2} \mathrm{O}=12288$ miles $\times 0.0062 \mathrm{gN}_{2} \mathrm{O}$ /passenger-mile $\times 298$

$$
\begin{aligned}
& =22703.3088 \mathrm{gCO}_{2}-\mathrm{e} \\
& =0.0227033088 \text { tonnes } \mathrm{CO}_{2}-\mathrm{e}
\end{aligned}
$$

\footnotetext{
16 Source: 2011 Guidelines to Defra / DECC's GHG Conversion Factors for Company Reporting. Version 1.0 FINAL updated July 2011. (The World Bank, 2015)

${ }^{17}$ Intergovernmental Panel on Climate Change, Fourth Assessment Report
} 
Total emissions from Long-Haul flights

$$
\begin{aligned}
& =2.371584+0.00024576+ \\
& 0.0227033088 \\
& =2.3945 \text { tonnes } \mathrm{CO}_{2}-\mathrm{e}
\end{aligned}
$$

Total emissions from business air travel $\quad=7.2531+2.3945$

$$
=9.6476 \text { tonnes } \mathrm{CO}_{2}-\mathrm{e}
$$

Summary

Total Scope 3 Emission

\begin{tabular}{lll}
\hline Source & Tonnes $\mathrm{CO}_{2}-\epsilon$ & Percentage \\
\hline Emission from business air travel & 9.6476 & $100 \%$ \\
$\bullet \quad$ Emissions from Medium-Haul flights & 7.2531 & $75.18 \%$ \\
$\bullet \quad$ Emissions from Long-Haul flights & 2.3945 & $24.82 \%$ \\
Total Scope 3 emission & 9.6476 & $100 \%$ \\
\hline
\end{tabular}

\section{Conclusion}

Hamdard University carbon emission was 1786.2019 tonnes of $\mathrm{CO}_{2}$-e in 2018. Which is $0.000547 \%$ of Pakistan 2014's GHG emission. Scope 1 direct emission which accounts for $54.14 \%$ is the major part of our total GHG emission followed by scope 2 emission which accounts for $45.32 \%$ which is caused by the consumption of electricity. Scope 3 emission which is a consequence of official air travel is only $0.54 \%$ with respect to our total GHG emission of Hamdard University.

Scope 1 emission consists of fuel combustion in transport followed by combustion of natural gas, and refrigerants which is $57.02 \%, 19.81 \%$, and $18.29 \%$ of total scope 1 emission respectively. Scope 2 emission entirely consists of purchased electricity from K-Electric. Scope 3 emission is negligible and consists of only official air travel of varsity.

Summary Carbon Footprint of Hamdard University

\begin{tabular}{ll}
\hline Source & Tonnes $\mathrm{CO}_{2}$-e Percentage \\
\hline Scope 1 emission: & \\
Emission from fuel (petrol) combustion by 47.2105 \\
generators
\end{tabular}


Emission from combustion of natural gas

191.5456

357.5263

193.9190

169.8219

7.072

967.0953

$54.14 \%$

Total Scope 1 emission

Scope 2 emission:

Emission from purchased electricity

809.459

$45.32 \%$

Scope 3 emission:

Emission from business air travel

- Emissions from Medium-Haul flights

- Emissions from Long-Haul flights

Total Scope 3 emission

9.6476

$0.54 \%$

Total Carbon Footprint of Hamdard University

\section{Limitation of Research}

This research is limited to Hamdard University Main Campus only. It doesn't include City Campus, Islamabad Campus and Hospital.

\section{Future Research}

The next part of this research is to mitigate the existing carbon emission of Hamdard University in the near future. To make Hamdard University a carbon neutral or a green university, we will offset the remaining emission from the green initiatives in the next part of our research in the future. The green university will contribute to the green economy. 


\section{References}

America's Climate Choices: Panel on Advancing the Science of Climate Change; National Research Council. (2010). Advancing the Science of Climate Change. Washington, D.C.: The National Academies Press.

CBC News. (2015, December 12). 'Historic' Paris climate deal adopted. CBC News: $\quad$ https://www.cbc.ca/news/world/cop21-climate-change-talkssaturday-announced-1.3362354

Chappell, B. (2015, December 12). Nearly 200 Nations Adopt Climate Agreement At COP21 Talks In Paris. NPR: https://www.npr.org/sections/thetwoway/2015/12/12/459464621/final-draft-of-world-climate-agreement-goesto-a-vote-in-paris-saturday

Cleveland, C. J., \& Morris, C. (Eds.). (2015). Dictionary of Energy. (2nd ed.). Elsevier. doi:10.1016/C2009-0-64490-1

Climate Change 2007: Impacts, Adaptation and Vulnerability (2007) Working Group II to the Fourth Assessment Report of Intergovernmental on Climate Change. Cambridge University Press.

Cole, D. H. (2008). Climate Change, Adaptation, and Development. UCLA Journal of Environmental Law and Policy, 26(1).

Commonwealth of Australia. (2017). National Carbon Offset Standard for Organizations: An Australian Government Initiative. https://apo.org.au/sites/default/files/resource-files/2017-11/aponid127996.pdf.

Farber, D. A. (2007). Adapting to Climate Change: Who Should Pay. Journal of Land Use \& Environmental Law, 23.

Intergovernmental Panel on Climate Change. (1996). Second Assessment Report. Press Syndicate of the University of Cambridge. https://www.ipcc.ch/site/assets/uploads/2018/02/ipcc_sar_wg_I_full_report .pdf 
IKreft, S., Eckstein, D., Junghans, L., Kerestan, C., \& Hagen, U. (2015). Global Climate Risk Index 2015. Germanwatch e.v. https://germanwatch.org/en/9470.

Lippert, I. (2011). Extended carbon cognition as a Machine. Computational Culture, (1), 17.

Pakistan State Oil. (n.d.). Pol Archives. Pakistan State Oil Web site: https://psopk.com/en/product-and-services/product-prices/pol/pol-archives

Recycling, R., \& Refrigerants, S. (2004). Environmental Protection Agency 40 CFR Part 82.

Stocker, T. (Ed.). (2014). Climate change 2013: the physical science basis: Working Group I contribution to the Fifth assessment report of the Intergovernmental Panel on Climate Change. Cambridge university press.

Schmidt, G. A., Ruedy, R. A., Miller, R. L., \& Lacis, A. A. (2010). Attribution of the present-day total greenhouse effect. Journal of Geophysical Research, 115. doi:10.1029/2010JD014287

The World Bank. (2015). The World Bank Group Greenhouse Gas Emissions Inventory Management Plan for Internal Business Operations 2014. http://documents.worldbank.org/curated/en/319541467991904684/pdf/999 42-WP-PUBLIC-Box393216B-FY-14-WBG-Inventory-ManagementPlan.pdf\#page $=37 \&$ zoom $=100,0,84$

U.S. Environmental Protection Agency. (2004). Climate Leaders - Direct HFC and PFC Emissions from Use of Refrigeration and Air-Conditioning Equipment. National Service Center for Environmental Publications (NSCEP).

United Nations Framework Convention on Climate Change. (2015). What is Paris Agreement.? https://unfccc.int/process-and-meetings/the-parisagreement/the-paris-agreement

United Nations Environment Programme. (2011). Towards a Green Economy: Pathways to Sustainable Development and Poverty Eradication. https://www.cbd.int/financial/doc/green_economyreport2011.pdf 
We Mean Business (2016). The Business End of Climate Change. https://www.wemeanbusinesscoalition.org/blog/the-business-end-ofclimate-change/

World Resource Institute. (2014). Greenhouse Gas Emissions Over 165 Years. World Resourse Institute: https://www.wri.org/resources/datavisualizations/greenhouse-gas-emissions-over-165-years 